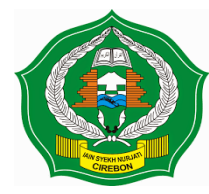

\title{
JIEM
}

(Journal Islamic Education of Management)

https://www.syekhnurjati.ac.id/jurnal/index.php/jiem

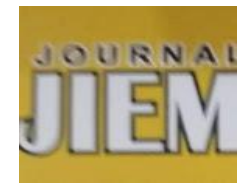

\section{KEPEMIMPINAN KEPALA TAMAN KANAK-KANAK ISLAM TERPADU SABILUL HUDA DALAM MANAJEMEN SEKOLAH}

\author{
Asep Kurniawan \\ Institut Agama Islam Negeri Syekh Nurjati Cirebon \\ asepkurniawan@syekhnurjati.ac.id
}

\begin{abstract}
Abstrak
Tujuan penelitian ini adalah untuk mengungkap secara mendalam tentang kepemimpinan kepala Taman Kanak-kanak Islam Terpadu Sabilul Huda dalam mengelola lembaga pendidikannya. Metode penelitian ini adalah kualitatif deskriptif eksplanatoris studi kasus. Teknik pengumpulan data menggunakan snowball sampling dengan instrumen wawancara mendalam, observasi mendalam, dan dokumentasi. Keabsahan data dilakukan melalui kredibilitas dengan cara ketekunan pengamat, triangulasi sumber, waktu, dan instrumen, serta bahan referensi yang memadai. Hasil penelitian menemukan bahwa kepala TKIT Sabilul Huda sudah menjalankan kepemimpinannya dalam menyusun perencanaan sekolah untuk setiap program pendidikan dengan cukup baik. Perencanaan yang sudah yang dimaksud meliputi rencana strategis dan rencana operasional. Kepala TKIT Sabilul Huda dalam menjalankan fungsi kepemimpinan dalam pengorganisasian sudah menyusun struktur organisasi dan pembagian wewenang dengan baik kepada bawahannya. Pembinaan diselenggarakan secara rutin guna memecahkan permasalahan yang ada yang dilaksanakan pada setiap permulaan semester. Manajemen peserta didik yang dilakukan melalui penerimaan peserta didik baru dilakukan pada setiap permulaan tahun ajaran baru. Manajemen sarana dan prasarana sudah cukup baik sehingga berdampak kepada proses efektifitas pembelajaran terutama dalam penanaman aspek religius. Hubungan kemitraan sekolah dengan masyarakat terjalin secara langsung. Peran kepimpinan kepala sekolah dalam menggerakkan manajemen keuangan sudah dikatagorikan cukup baik. Hal ini dilihat dari kondisi keuangan yang surplus. Pelaksanaan fungsi pengawasan dari kepemimpinan kepala TKIT Sabilul Huda dilakukan secara ketat dan dalam bentuk evaluasi yang terencana.
\end{abstract}

Kata kunci: Pengaruh, Kinerja, Manajemen, Sumber Daya

\section{Abstract}

The purpose of this study was to reveal in-depth the leadership of the head of Islamic full-day Kindergarten Sabilul Huda in managing his educational institutions. This research method was a qualitative case study of descriptive explanatory. Data collection technique was snowball sampling with in-depth interview instruments, in-depth observation, and documentation. The validity of the data was done through credibility by the perseverance of the observer, triangulation of sources, time, instruments, and adequate reference material. The results found that the head of Islamic full-day Kindergarten Sabilul Huda carried out her leadership in making school plans properly for all educational programs. Planning included strategic plans and operational plans. In organizing, she made the organizational structure and distributed authority to her subordinates. Coaching was done to solve problems at the 
beginning of the semester. At the beginning of every new school year, student management was done through the acceptance of new students. Management of facilities and infrastructure was good enough so that it had an impact on the effectiveness of learning processes, especially in instilling religious aspects. The relationship between the school and the community was directly established. The principal's role in driving financial management was good. It could be seen from the surplus financial condition. The implementation of the supervisory function of her leadership was carried out rigorously through evaluation.

Keywords: Influence, Performance, Management, Resources

\section{A. Pendahuluan}

Sekolah adalah lembaga penting dalam menyelenggarakan proses pendidikan. Pada akhirnya, secara makro pendidikan akan berujung pada sekolah melalui proses belajar mengajar. Kepala sekolah sebagai pemimpin amat berperan dalam menggerakkan semua komponen di sekolah sehingga proses pembelajaran dapat terlaksana dengan baik. Kepala sekolah merupakan tokoh utama dalam peningkatan kualitas, daya saing dan relevansi pendidikan. Peran kepala sekolah cukup strategis dalam upaya merealisasikan sekolah yang berkualitas dan mempunyai daya saing global sejalan cita-cita dan arah pendidikan menuju manusia Indonesia yang kompetitif dan cerdas.

Hal ini mengingat, kepemimpinan adalah penggerak penting organisasi dalam posisinya sebagai agent of change dan peran manajerial yang dilaksanakannya sehingga pemimpin tidak saja sebagai simbol organisasi, akan tetapi memiliki pengaruh positif untuk perkembangan organisasi (Ryan, 2008). Kepemimpinan kepala sekolah adalah unsur kunci dalam organisasi sekolah (Huber, 2004).

Kepala Taman Kanak-kanak (TK) atau Taman Kanak-kanak Islam Terpadu adalah tenaga fungsional guru yang mendapakan tugas untuk memimpin institusi pendidikan formal tempat dilaksanakannya proses belajar mengajar ataupun tempat berlangsungnya interaksi antar guru yang memberikan pelajaran dengan peserta didik yang menerima pelajaran. Dalam melaksanakan perannya, seorang kepala sekolah Taman Kanakkanak tentu saja mesti bisa menyusun perencanaan yang komprehensif, berkelanjutan, terpadu, dan sistematis. Perencanaan dalam pendidikan ialah tercapainya tujuan pendidikan secara efektif dan efisien dengan kualitas pendidikan yang memberikan kepuasan kepada para stakeholder dan pelanggannya. Perencanaan yang meliputi kejelasan dan penegasan visi, misi, tujuan, dan strategi organisasi ialah hal penting untuk dicermati oleh berbagai pihak yang 
berkepentingan terhadap pendidikan, agar organisasi bisa meraih keberhasilan (Suhardiman, 2012: 1-3). Kepala sekolah merupakan manajer dalam institusi pendidikan, maka kepala sekolah berperan untuk mengelola potensi yang ada (sarana dan prasarana, karyawan sekolah, guru) agar bisa berfungsi secara maksimal. Keterampilan manajerial dibutuhkan oleh manajer agar bisa menjalankan tugas manajerialnya dengan efektif.

TKIT Sabilul Huda ialah Taman Kanak-kanak Islam terpadu (TKIT) yang memiliki daya tarik bagi para orang tua untuk menyekolahkan anaknya. Kesuksesan ini disebabkan oleh sejumlah faktor, diantaranya ialah kepala sekolah dalam melaksanakan fungsi dan perannya sebagai manajer. TKIT Sabilul Huda ialah satu dari sejumlah besar TK swasta yang ada di Kota Cirebon yang berdiri sejak tahun 2002. Sekolah ini mengalami kemajuan dan perkembangan yang cukup pesat, baik dari sisi jumlah siswa maupun sarana prasarana yang terus meningkat.

Bertitik tolak penjelasan di atas, ada sejumlah alasan yang memotivasi untuk melakukan studi ini. Pertama, pendidikan TKIT ialah sebuah pendidikan penting yang menjadi landasan bagi level pendidikan dasar, diharapkan dengan kuatnya landasan pendidikan usia dini, maka pendidikan dasar akan memiliki dasar yang kuat, sehingga siswa bisa mengembangkan dan memiliki karakter sejalan dengan yang diharapkan dalam dunia pendidikan. Kedua, kemajuan di bidang pendidikan memerlukan administrator pendidikan yang bisa mengelola lembaga pendidikan dan dapat meningkatkan kinerja guru dalam merealisasikan tujuan pendidikan. Ketiga, studi empiris dengan tofik ini menarik untuk dilaksanakan mengingat perkembangan teori dan ilmu manajemen pendidikan, yang senantiasa berkembang mengikuti perkembangan zaman.

\section{B. Metode Penelitian}

Penelitian ini merupakan penelitian kualitatif studi kasus deskriptif eksplanatoris (Kurniawan, 2018: 30). Pendekatan kualitatif berupaya mengumpulkan banyak data deskriptif, untuk diwujudkan dalam wujud gambaran yang didapatkan dari karya-karya ilmiah, dokumen, catatan lapangan, dan lain-lain (Margono, 2005: 36). Jenis penelitian ini digunakan sebab mengeksplorasi fenomena yang kompleks dari individu, program atau organisasi yang kompleks sebagaimana yang terjadi dalam dunia pendidikan (Yin, 2009: 4; Baxter \& Jack, 2008: 544).

Data penelitian ini dianalisis secara berkesinambungan sejak permulaan sampai akhir penelitian dan bergerak secara deduktif ataupun induktif, termasuk 
juga melalui mengembangkan teori dan sintesis. Penelitian ini ialah inkuiri empiris yang mengungkap fenomena dalam konteks kehidupan yang sesungguhnya, jika batas-batas antara konteks dan fenomena tidak nampak dengan tegas dan di mana berbagai sumber bukti dipergunakan (Yin, 2002: 18). Penelitian ini dilaksanakan di TKIT Sabilul Huda, yang bertempat di Jl. Perjuangan No.20, Kelurahan Karyamulya, Kecamatan Kesambi, Kota Cirebon

Teknik pengumpulan data penelitian ini ialah snowball sampling yaitu, mengumpulkan data sebanyak mungkin dari penentuan sampel yang pada awalnya jumlahnya kecil atau sedikit lalu membesar (Kurniawan, 2018: 291). Dalam pengumpulan data, penelitian ini menggunakan yakni wawancara mendalam, observasi mendalam, dan dokumentasi. Teknik analisis data dilakukan melalui sejumlah tahapan: pengumpulan data, reduksi data, display data, dan pengambilan kesimpulan. Untuk menjaga keabsahan data ditempuh melalui kredibilitas dengan cara ketekunan pengamat, triangulasi sumber, waktu, dan instrument, serta bahan referensi yang memadai.

\section{Temuan dan Pembahasan}

Memajukan taman kanak-kanak Islam Terpadu (TKIT) Sabilul Huda diupayakan melalui proses pembuatan renstra (rencana strategis), renstrop (rencana operasional), rencana tahunan yang berisi berupa rencana kegiatan, jadwal, dan rencana pendapatan dan penggunaan dana, dan RAPBS (Rencana Anggaran Belanja Sekolah). Untuk sumber data bisa diungkapkan dari dalam proses wawancara mendalam, observasi mendalam terhadap beberapa orang guru, staf kependidikan dan kepala sekolah, serta dokumentasi (Pebruari sampai Juni 2019). Penulis mendapatkan data bahwa kepemimpinan kepala TKIT Sabilul Huda diwujudkan dalam penyusunan rencana pengembangan sekolah tersebut dilakukan setiap akhir semester. Hal ini dilakukan pada rapat guru, pengurus yayasan dan kepala sekolah yang mendiskusikan agenda rapat mengenai rencana pengembangan sekolah yang kelak akan dijadikan acuan sekolah dalam pelaksanaan program selama satu semester ke depan, dan nantinya akan ada rapat dalam satu semester sejumlah dua kali untuk mendapatkan kritikan dan saran dari tingkat bawahan kepada kepala sekolah (bottom-up) sehingga kelak bisa dipakai untuk menetapkan kebijakan berikutnya. Hal tersebut juga menjawab mengenai prinsip akuntabilitas dan transparansi, serta melibatkan semua sivitas sekolah. Dari 
umpan balik dari para bawahan ini selanjutnya dijadikan sebagai acuan manajemen sekolah. Penyusunan proposal kegiatan adalah menyangkut kegiatan-kegiatan yang diselenggarakan di TKIT Sabilul Huda. Sebagaimana dijelaskan oleh Titi Inayati, selaku kepala sekolah bahwa dalam satu semester pihak sekolah menyusun setidaknya satu proposal di awal semester atau di awal tahun ajaran baru. Hal ini dimaksudkan agar program pembelajaran dan program pendidikan sekolah secara umum dapat terlaksana dengan baik sejalan dengan yang tertera di dalam proposal.

Hal ini artinya menunjukkan kepala sekolah sudah menjalankan peran kepemimpinannya sebagai penggerak organisasi yang diawali dari tahapan awal manajemen, yaitu perencanaan. Sebagaimana dikatakan oleh Robbins dan Judge bahwa kepemimpinan (leadership) adalah kompetensi untuk mempengaruhi suatu kelompok guna mencapai tujuan yang ditentukan (2015: 249). Kepemimpinan yang dipraktekkan oleh kepala TKIT Sabilul Huda, menurut Dubrin adalah usaha untuk mempengaruhi orang banyak melalui komunikasi. Komunikasi adalah bagian penting dari kepemimpinan. Seorang pemimpin dapat saja masuk ke ruangan kerja bawahannya dan memberi pujian sebab ia sudah berhasil mendapatkan banyak yang potensial (2006: 4).

Demikian pula hasil penggalian dari sejumlah guru, bahwa di setiap akhir semester sesudah pembagian raport hasil belajar siswa, sekolah menyusun proposal kembali untuk satu semester ke depan dan para sivitas sekolah memahami pentingnya penyusunan proposal dan implementasinya. Ibu Titi Inayati selalu kepala sekolah mendiskusikan hal ini, sharing ide dengan para guru dan tenaga kependidikan bagi pengembangan program pendidikan ke depan. Pengembangan program ini diantaranya penyusunan silabus materi pelajaran, pengembangan kurikulum seperti muatan lokal, dan lain-lain. Fakta ini nampaknya menjadi suatu kemestian bagi kepala TKIT Sabilul Huda dan guru-guru pada setiap permulaan semester agar programprogram pendidikan yang dimaksud bisa terlaksana dengan baik sejalan dengan yang sudah direncanakan.

Peran kepemimpinan kepala TKIT Sabilul Huda dalam pengorganisasian, dilakukan melalui penyusunan dan pembentukan gugus kerja sebagai wujud pembagian wewenang struktur organiasasi antara sivitas sekolah serta hubungan antar 
sesamanya agar bisa terwujud suatu budaya kerja untuk terealisasinya tujuan pendidikan yang sudah ditetapkan. Berpijak kepada wawancara mendalam dengan kepala sekolah bahwa struktur organisasi di TKIT Sabilul Huda nampaknya sedikit berbeda jika dibandingkan dengan Taman Kanakkanak pada umumnya. Di lembaga pendidikan ini, Ibu Titi Inayati selaku kepala sekolah dibantu oleh wakil kepala sekolah dengan wewenang yang lebih relatif lebih luas, yaitu berkaitan dengan kinerja keseharian guru. Sementara itu, kepala sekolah menangani persoalan yang berkaitan dengan pihak luar dan melakukan pengawasan terhadap kinerja wakil kepala sekolah. Dari hasil observasi mendalam penulis secara partisipan pasif di TKIT Sabilul Huda (4 Maret-25 Maret 2019) dan wawancara mendalam (18-22 Maret 2019) bisa difahami bahwa di TKIT ini manajemen melalui tahapan pengorganisasian sudah berjalan dengan cukup baik.

Fakta di atas memperlihatkan bahwa kepala TKIT Sabilul Huda cukup memiliki keterampilan konsep yang cukup memadai melalui pengorganisasian, pengkoordinasian terhadap pembagian wewenang kerja. Conceptual skills ialah kompetensi seorang pemimpin dalam melihat organisasi sebagai satu totalitas, mengetahui fungsi-fungsi organisasi yang saling mempengaruhi dan ketergantungan, mengkoordinasikan dan mengintegrasikan semua kegiatan, kepentingan dan pandangan dari individu dan kelompok ke dalam satu organisasi sebagai suatu totalitas (Andelkovic, 2017: 9; Motlaq dan Motlaq, 2012).

Fakta dari penelitian ini menunjukkan bahwa kepemimpinan kepala TKIT Sabilul Huda ditunjukkan dalam perencanaan yang baik terhadap kebutuhan sekolah, termasuk tenaga kependidikan dan guru. Sementara itu, bagi pengembangan sumber daya manusia (SDM) organisasi, dalam hal ini guru-guru diselenggarakan secara rutin di penghujung semester. Pengembangan SDM ini berupa pelatihan dan penggemblengan mental di saat para siswa sedang libur, akan tetapi guru-guru dan para staf serta satpam sekolah tetap masuk kerja. Pelatihan ini terkait dengan upaya peningkatan kompetensi-kompetensi guru baik professional, sosial, pedagogik, maupun kepribadian. Disamping itu pengembangan SDM sekolah dilakukan pula melalui forum kelompok kerja guru dan karyawan.

Adapun mengenai peran kepemimpinan kepala sekolah dalam 
manajemen sarana prasarana belajar di TKIT Sabilul Huda, menurut penulis sudah dapat dikatagorikan cukup baik. Hal ini dapat dilihat dari sarana prasarana yang ada sudah dapat dinilai memadai, seperti ruang kelas baik ukuran maupun kelengkapannya sudah memenuhi standar dengan luas kurang lebih 7 × $8 \mathrm{~m}$ dengan slogan edukatif, gambar-gambar pendidikan yang menarik, begitu pula dengan kursi dan meja yang dicat berwarna-warna sehingga terlihat hidup dan menarik. Penulis mendapati sarana ibadah berupa masjid sekolah yang cukup besar berukuran sekitar 17 x 15 m. Demikian pula dengan alat-alat bermain yang ada di halaman sekolah.

Sesuai dengan eksistensi TKIT sebagai lembaga pendidikan usia dini yang bernafaskan pendidikan karakter Islam, penulis mendapatkan denyut suasana pembelajaran yang cukup sarat dengan program-program relijius, seperti pembelajaran berwudhu, membaca al-Qur'an (membaca dengan metode qira'ati di kelas dan khotmil Qur'an di masjid), membaca do'a sebelum dan sesudah belajar, tegur sapa dan salam, pembiasaan shalat berjama'ah di kelas. Untuk yang terakhir ini tidak dimungkinkan dilakukan di masjid sekolah karena pertimbangan para siswa masih kanak- kanak sehingga hawatir mengganggu jama'ah yang lain.

Dalam kaitannya dengan hubungan kemitraan dengan masyarakat, kepemimpinan kepala TKIT diwujudkan dalam pencarian dukungan dari masyarakat bagi kelancaran pelaksanaan programprogram pendidikan. Hubungan ini mesti dilakukan, seperti dalam beberapa kesempatan terutama di awal tahun ajaran dan akhir semester sambil membagikan hasil belajar siswa, sekolah meminta dukungan dari para orang tua siswa untuk membantu membimbing anak-anaknya yang sekolah di TKIT Sabilul Huda dalam mendalami kemampuan siswa selepas pulang dari sekolah, seperti untuk tetap membimbing mereka membaca alQur'an dan shalat-shalat fardhu. Disamping itu, berdasarkan hasil wawancara dengan kepala TKIT Sabilul Huda (8 Mei 2019), penulis mendapatkan data bahwa aktivitas yang lebih menekankan terhadap orangtua dilakukan oleh masing-masing guru dengan memberi waktu untuk berdiskusi dengan para orangtua dalam setiap harinya secara terbuka (observasi 29 Maret - 4 Mei 2019). Bisanya dilakukan oleh para guru dengan orang tua siswa selagi mereka menunggu anak-anak pulang sekolah baik di kantin 
sekolah maupun di serambi masjid sekolah. Dengan demikian, perkembangan para siswa dalam setiap harinya bisa diketahui oleh para orangtua.

Temuan di atas menunjukkan bahwa kepala sekolah telah memerankan kepemimpinannya dengan cukup baik sehingga memunculkan kerjasama di dalam organisasi (human skills). Sejalan dengan hal tersebut dalam berbagai referensi menjelaskan bahwa human skills ialah kecakapan pemimpin untuk bekerja dengan efektif sebagai anggota kelompok dan untuk menumbuhkan upaya kerjasama di lingkungan organisasi yang dipimpinnya (Moore dan Rudd, 2004: 23 ; 477).

Keberadaan masjid sekolah yang cukup besar dan representatif tidak saja dipergunakan bagi pembiasaan beribadah dan pendidikan karakter para siswa, tetapi juga dipergunakan bagi masyarakat umum untuk beribadah, diantaranya shalat jum'at. Pada momen ini sekolah memanfaatkan pula bagi penyebaran pesan-pesan sekolah yang perlu diketahui masyarakat luas. Misalnya tentang program zakat dan qurban yang meminta partisipasi masyarakat. Artinya dalam hal ini, penulis menangkap kesan bahwa sekolah sudah berupaya untuk melakukan berbagai tindakan bagi pengembangan kemitraan dengan masyarakat.

Disamping itu, diantara unsur penting dalam manajemen pendidikan ialah peserta didik. Berdasarkan hasil dari wawancara dengan kepala sekolah dan sejumlah guru (wawancara 2 Mei 2019) memperlihatkan bahwa kepala sekolah dalam kepemimpinannya telah menggerakkan bawahannya atau para guru untuk menyusun rencana pembelajaran dengan baik dalam penerimaan peserta didik baru dan tahap-tahap berikutnya, sehingga seluruh rangkaian proses pembelajaran bisa terlaksana dengan lancar. Hal ini artinya mengikuti aturan yang ditetapkan kementerian pendidikan. Contoh sekolah merencanakan pengembangan rombongan belajar yang baru, kemudian sekolah target tertentu, seperti jumlah siswanya atau rungan belajar, pengelompokan dan penempatannya yang dilakukan berdasar usia dan lain-lain, maka selanjutnya direalisasikan langsung diimplementasikan. Hal ini mengingat jumlah pendaftar dari tahun ke tahun senantiasa meningkat walaupun seiring dengan hal tersebut biaya pendidikan pun meningkat pula. Artinya dapat difahami sekolah ini memiliki tingkat 
kepercayaan yang cukup tinggi dari masyarakat.

Penggerakan bawahan dalam manajemen peserta didik ini memperlihatkan bahwa kepala sekola sudah memiliki technical skills selaku pemimpin. Technical skills ialah keterampilan secara spesifik mengenai teknik-teknik, prosedur, proses atau kecakapan khusus dalam menganalisis hal-hal yang bersifat khusus dan penggunaan sarana prasarana dan teknik-teknik pengetahuan yang berkaitan dengan barang (Moore dan Rudd, 2004: 23; 477; Hysong, 2008: 276).

Unsur yang lain dalam manajemen pendidikan di TKIT Sabilul Huda adalah manajemen keuangan yang merupakan unsur penting bagi pengembangan mutu pendidikan. Manajemen keuangan yang cukup ikut menentukan banyaknya kegiatan dan program yang bisa dilakukan. Secara umum manajemen keuangan di TKIT Sabilul Huda yang dipimpin oleh kepala sekolah sebagai penanggungjawab tertinggi keuangan terhadap guru dan staf yang menangani tugas ini, sudah dilakkukan dengan baik dan menerapkan prinsip transparansi serta akuntabilitas. Manajemen keuangan utamanya disusun di awal tahun ajaran baru. Hal ini dapat ditinjau dari aktivitas penggalangan sumber keuangan atau pendapatan sekolah, pemanfaatan keuangan, dan penyimpanan keuangan (tabungan sekolah) yang telah terencana dengan baik dan terarsipkan dengan rapi di staf keuangan berikut bukti dan kwitansi penggunaanya. Keungan sekolah tidak mengalami defisit, bahkan dapat senantiasa setiap tahunnya terjadi surplus keuangan yang dipergunakan untuk disimpang (ditabung) bagi pengembangan sekolah. Untuk menjalankan roda pendidikan di sekolah ini berasal dari banyak sumber, yaitu dari bantuan pemerintah walaupun sifatnya tidak rutin, dari para donator, dan utamanya dari para orang tua siswa.

Selaku pimpinan TKIT Sabilul Huda, Ibu Titi Inayati berperan dalam memberikan bimbingan dan motivasi bagi peningkatan kinerja guru dan staf untuk bisa optimal dan memecahkan permasalahan yang ada. Upaya ini dilakukan dengan berbagai pendekatan baik formal maupun non formal. Pendekatan formal dilakukan dalam posisi kepala sekolah yang menempati posisi tertinggi dalam struktur organisasi sekolah dengan memberikan bimbingan dan motivasi dalam acaraacara rapat. Sedangkan pendekatan non formal dilakukan kepala sekolah dalam acara penyegaran atau keakraban antara 
sivitas sekolah seperti dalam acara outbound dan rekreasi.

Langkah akhir dalam peran manajerial kepala sekolah adalah pengawasan. Pengawasan secara umum meliputi beberapa langkah yang ditempuh, yakni menetapkan suatu standar atau kriteria, mengukur nilai kinerja, membandingkan kinerja dengan standar yang sudah ditentukan, dan memperbaiki kesalahan yang tidak sesuai dengan standar dengan tindakan koreksi. Dalam hal ini, berdasarkan hasil observasi penulis (29-30 April 2019) kepala TKIT Sabilul Huda telah melakukan pengawasan terhadap program pendidikan dengan baik. Pengawasan kepala sekolah dalam satu semester dilakukan dalam bentuk evaluasi yang terencana, setidaknya sekali dalam satu. Sedangkan data hasil pengamatan mendalam dapat terungkap bahwa proses pengawasan dilakukan cukup ketat baik oleh kepala TKIT, wakil kepala sekolah, ataupun oleh pengurus Yayasan Sabilul Huda. Guruguru berpandangan bahwa program pembinaan yang dilaksanakan oleh kepala sekolah telah sangat beragam, contohnya kegiatan outbound guna meningkatkan motivasi, silaturahmi, dan kebersamaan guru.

\section{Kesimpulan}

Kepala TKIT Sabilul Huda sudah menjalankan kepemimpinannya dalam menyusun perencanaan sekolah untuk setiap program pendidikan dengan cukup baik. Perencanaan yang sudah yang dimaksud meliputi rencana strategis dan rencana operasional. Penyusunan perencanaan sekolah, kepala sekolah melibatkan guru-guru, dan pengurus yayasan. Kepala TKIT Sabilul Huda dalam menjalankan fungsi kepemimpinan dalam pengorganisasian sudah menyusun struktur organisasi dan pembagian wewenang dengan baik kepada bawahannya. Pendayagunaan sumber daya manusia dilakukan melalui Pelatihan dan forum kelompok kerja guru dan karyawan. Pembinaan diselenggarakan secara rutin guna memecahkan permasalahan yang ada yang dilaksanakan pada setiap permulaan semester. Manajemen peserta didik yang dilakukan melalui penerimaan peserta didik baru dilakukan pada setiap permulaan tahun ajaran baru. Pengelompokan dan penempatan peserta didik dilakukan berdasarkan usia. Manajemen sarana dan prasarana sudah cukup baik sehingga berdampak kepada proses efektifitas pembelajaran terutama dalam penanaman aspek religius. Hubungan kemitraan sekolah dengan masyarakat 
terjalin secara langsung dalam pembagian laporan hasil belajar dan pertemuan di sarana ibadah. Peran kepimpinan kepala sekolah dalam menggerakkan manajemen keuangan sudah dikatagorikan cukup baik. Hal ini dilihat dari kondisi keuangan yang surplus. Pelaksanaan fungsi pengawasan dari kepemimpinan kepala TKIT Sabilul Huda dilakukan secara ketat dan dalam bentuk evaluasi yang terencana.

\section{Daftar Pustaka}

Andelkovic, Marija. 2017. "Conceptual Skills in Persons with Visual Impairment". Specijalna edukacija $i$ rehabilitacija (Beograd), 16 (1), 933.

Baxter, P., \& Jack, S. 2008. "Qualitative Case Study Methodology: Study Design and Implementation for Novice Researchers". The Qualitative Report, 13 (4), 554-559.

Ghalandari, Kamal. 2012. "Investigation of the Effect of Management Skills (Technical, Human and Cognitive) on Productivity of Human Resources in Iran". World Applied Sciences Journal, 20 (3): 476-480.

Hysong, Sylvia. 2008. "The Role of Technical Skill in Perceptions of Managerial Performance". Journal of Management Development, 27 (3), 275-290.

Huber, S. G. (2004). "School Leadership and Leadership Development: Adjusting Leadership Theories and Development Programs to Values and the Core Purpose of School". Journal of Educational Administration, 42 (6), 669-684.
Kurniawan, Asep. 2018. Metodologi Penelitian Pendidikan. Bandung: Remaja Rosdakarya.

Margono. 2005. Metodologi Penelitian Pendidikan. Jakarta: Rineka Cipta

Moore, Lori, dan Rick D Rudd. 2004. "Leadership Skills and Competenices For Extension Directors And Administrators". Journal of Agricultural Education, 45 (3), 22-33.

Motlaq, Mostafa Akbari, dan Maryam Akbari Motlaq. 2012. "The Effect of Conceptual Skills Training on the Degree of Job Satisfaction and Performance in Women Managers". Conference: The First International Conference of Women's Health.

Ryan, Will. 2008. Leadership with a Moral Purpose: Turning your School Inside Out. Wales: Crown House Publishing Ltd.

Suhardiman, Budi. 2012. Studi Pengembangan Kepala Sekolah. Jakarta: Rineka Cipta.

A. Yin, R. K. 2009. Case Study Research: Design and Methods. California: Sage Publications, Inc. 